\title{
CORRESPONDENCE
}

The Editor,

Journal of Glaciology

SIR,

\section{About the origin of rock glaciers}

I do not wish to enter into a public controversy with W. Haeberli about the origin of rock glaciers; he has always been deaf to my arguments. Nevertheless, the readers of his passionate assertions (Haeberli, 1989) must be aware that he intentionally omits to quote my detailed observations in the dry Andes (Lliboutry, 1955, 1965, 1986). The concept that many rock glaciers come from old glaciers, or from "buried glacierets" (i.e. debris-rich glacierets, entirely covered at the end of the ablation season, and not nourished by ice every year) is not at all "purely speculative", as he says. If an interested glaciologist comes to Grenoble, I can show him the aerial photograph coverage of the area that $I$ have studied, with scores of such rock glaciers.

I do not deny that many (not all) rock glaciers are below melting point at depth. In this case, they consist of permafrost, but should slide on unfrozen ground .... Nevertheless, for the advancement of science, the essential point is not "must rock glaciers be left to scientists claiming to be permafrost specialists" but "what can we learn from the existence of rock glaciers in a given area"? I maintain that the geographical study of rock glaciers as an extreme case of glacier fluctuations, as an indicator of favourable mass balances in the past, or of past surges, would be much more rewarding than to consider them as a mere case of standard permafrost, or of creeping regolith.

\section{[Université Joseph Fourier]}

Laboratoire de Glaciologie et Géophysique

LOUIS LLIBOUTRY

de l'Environnement du CNRS.

38402 Saint-Martin-d'Heres Cedex.

France

\section{October 1989}

\section{REFERENCES}

Haeberli, W. 1989. Glacier ice-cored rock glaciers in the Yukon Territory, Canada? J. Glaciol., 35(120), 294-295.

Lliboutry, L. 1955. Origine et évolution des glaciers rocheux. C.R. Acad. Sci. (Paris), 240, 1913-1915.

Lliboutry, L. 1965. Traité de glaciologie. Tome 2. Glaciers, variations du climat, sols gelés. Paris, Masson.

Lliboutry, L. 1986. Rock glaciers in the dry Andes. Mater. Glyatsiol. Issled., 58, 139-144.

SIR,

An unusual jökulhlaup involving potholes on Black Rapids Glacier, Alaska Range, Alaska, U.S.A.

Black Rapids Glacier is a large valley glacier in the Alaska Range which surged in 1936-37 (Hance, 1937) and was dubbed the "galloping glacier" by the popular press. The glacier surface is covered by several hundred potholes near the equilibrium line (Sturm, 1987). These depressions or cauldron-like pits, $10-100 \mathrm{~m}$ across, are occasionally water-filled, and are thought to be a complex surface and englacial water system that is unique to surging glaciers. Twenty-six fields of potholes have been identified on the glaciers of Alaska and Yukon Territory; virtually all are on surging glaciers (though more than 200 surging glaciers do not have fields of potholes) (Sturm, 1987). Due to the remote location of most of these glaciers, including Black Rapids Glacier, there have been few direct observations of potholes filling or draining, and the nature of the water system connecting the potholes is poorly known.

On 16 August 1989, we observed water draining from a marginal ice-dammed lake and flowing through several potholes on Black Rapids Glacier in a manner that confirmed that the pothole-drainage system was both supraand englacial. The jökulhlaup was coming from a lake located along the north margin of the glacier (Fig. 1-A) which has a history of being the source of jökulhlaups. A distinctive strandline on the ice surface indicated that water had recently been at least $20 \mathrm{~m}$ above the current lake surface (Fig. 1-B). The lake, which is over $1000 \mathrm{~m}$ long when full, probably fills and drains every summer. It was observed draining on 10 August 1985, and a draining event was photographed in July 1987 using an automatic $8 \mathrm{~mm}$ movie camera (unpublished data of $\mathrm{T}$. Clarke). In both years, the discharge was englacial. In March 1984, the water level in the lake rose several meters and fractured a thick ice cover, even though below-freezing air temperatures prevailed and there was no surface run-off, suggesting that there was a significant recharge of water into the lake from an englacial source (personal communication from $M$. Wumkes, 1987).

In 1989, the discharge from the lake was supraglacial. Water flowed approximately $800 \mathrm{~m}$ through a vertical-walled canyon incised at least $20 \mathrm{~m}$ into the ice surface (Fig. 1-C) This canyon had several sharply angled bends in it, suggesting that fractures or weaknesses in the ice controlled its location.

The canyon ended where the water disappeared into the ice. Several hundred meters farther down-glacier the water emerged in a pothole that was approximately $50 \mathrm{~m}$ in diameter (Fig. 1-D). It was unmistakable that the water in the pothole was coming from the lake because both contained turbid, brown water, in contrast to the clear water seen elsewhere on the glacier surface. Water flowed over the down-glacier lip of the pothole, then through a shallow channel to a second pothole (Fig. 1-E). It cascaded into the second pothole in a waterfall which was at least $10 \mathrm{~m}$ high. The water in this pothole was observed to be swirling rapidly in a clockwise direction, suggesting that it was draining through a hole in the bottom of the pothole. The water carried numerous small icebergs and bits of ice. Dozens of small icebergs were stranded above the water surface along the down-glacier end of the pothole, indicating that the water level had been higher in the recent past.

The water flowed under the ice for several hundred meters and emerged in a third pothole (Fig. 1-F), where it was upwelling in a boil with significant super-elevation. Water flowed out of the third pothole and over the surface of the ice in a poorly defined, shallow channel into a fourth pothole (Fig. 1-G). The pothole is located at the extreme down-glacier end of the pothole field. Water flowed out of this pothole in a sheet which spread over the surface of the ice. During the $2 \mathrm{~h}$ we were in the vicinity, the sheet of water propagated several hundred meters downglacier along the ice surface, covering a swath hundreds of meters wide. Crevasses, which are numerous in the section of glacier below the pothole field, were filled with water as the flood passed (Fig. 1-H).

Our observations verify several characteristics of potholes which we have suspected were true. First, potholes 


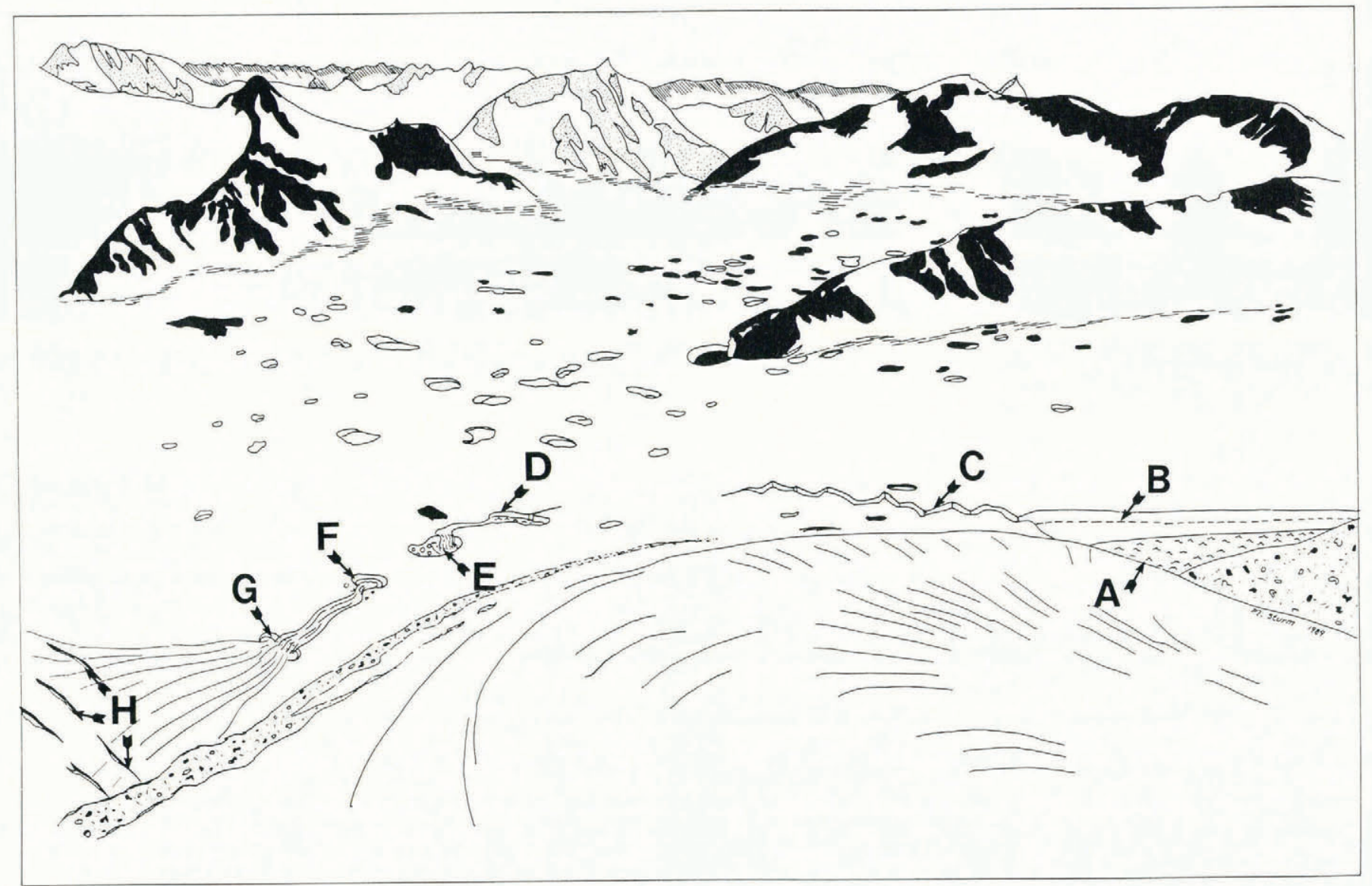

Fig. I. The pothole field of Black Rapids Glacier in the Alaska Range, central Alaska. The glacier. which is about $4 \mathrm{~km}$ wide, is flowing from right to left. The view is south; the nearest potholes are between 20 and $150 \mathrm{~m}$ in diameter. In the foreground, a small tributary glacier is pushing into the main trunk glacier; the surface of this glacier is split by radial crevasses. Features marked with letters are explained in the text.

are connected by complex englacial and supraglacial drainage systems that persist from year to year. We conclude this because the transition between surface and englacial flow observed in the 1989 jökulhlaup could only have occurred if the surface water had connected with an existing tunnel system. However, the tunnel system must evolve slowly, since the drainage pattern of the 1985 and 1987 jökulhlaups differed from that observed in 1989. Secondly, the drainage system in the area of the potholes differs from the drainage system found elsewhere on the glacier. In the pothole field, most surface features (primarily potholes) connect to an englacial water system; elsewhere, most surface features (crevasses) do not. This is illustrated by the fact that within the pothole field the water flowed from one pothole to another, but elsewhere, the spreading sheet of water filled only those crevasses that were directly in its path, and none of these crevasses diverted the flow into an englacial water system.

We do not know why the drainage system in the pothole field develops in such a distinctive manner, nor if it is connnected to the basal water system, which is known to play a key role in surging (Kamb and others, 1985). We feel that it would be valuable to monitor the pothole field through an entire surge cycle in order to understand better the relationship between potholes and surging.

\section{U.S. Army Cold Regions Research and Engineering Laboratory,}

Matthew Sturm

\section{Hanover.}

New Hampshire 03755-1290, U.S.A.

Geophysical Institute,

University of Alaska,

Fairbanks,

Alaska 99705, U.S.A.

19 September 1989

\section{REFERENCES}

Hance, J.H. 1937. The recent advance of Black Rapids Glacier, Alaska. J. Geol., 45, 775-783.

Kamb, W.B., and 7 others. 1985. Glacier surge mechanism: 1982-1983 surge of Variegated Glacier, Alaska. Science, 227(4686), 469-479.

Sturm, M. 1987. Observations on the distribution and characteristics of potholes on surging glaciers. J. Geophys. Res., 92(B9), 9015-9022.

SIR,

Comments on: "Character of the englacial and subglacial drainage system in the lower part of the ablation area of Storglaciären, Sweden, as revealed by dye-trace studies"

Dye tracing through glaciers provides one means of studying the inaccessible glacial drainage system. Unfortunately, the complex, unstable character of the drainage system, rapid variations of discharge, and high sediment concentrations make the tracing in the glacial environment challenging. The recent paper by Seaberg and others (1988) constitutes perhaps the best work to date on glacier tracing by virtue of high-quality data, replicate tracing, and systematic analysis. However, there may be alternative explanations for some of their data.

The tracer break-through curve obtained at the glacier snout results from dispersion, dilution, and flow routing. Seaberg and others considered the englacial flow route to be a homogeneously braided open channel with dramatic increases in sinuosity with stage accounting for the proportional relationship between travel time and discharge. They attributed occasional multiple-peaked break-through curves to temporary development of a few dominant flow routes from the homogeneously braided channel. 